BIOTECHNOLOGY

EDITOR

Douglas K. McCormick

MANAGING EDITOR

Susan Hassler (New York)

RESEARCH EDITOR

Harvey Bialy (New York)

ARTICLES EDITOR

John Hodgson (London)

B.J. Spalding (New York)

\section{NEWS EDITOR}

SENIOR EDITOR

Stephen M. Edgington (New York)

CONTRIBUTING EDITORS

Joseph Alper (St. Paul, MN)

Bernard Dixon (London)

Jeffrey L. Fox (Washington, D.C.)

Russ Hoyle (New York)

\section{ART DIRECTOR}

Lou Pippo

\section{EDITORIAL ASSISTANT}

Claire M. Corcoran

ASST. ART DIRECTOR Edna D. Thomas

PROJECT EDITOR Mark Goodstein

\section{PUBLISHER}

Andy Sutherland

VICE PRESIDENT - SALES

Marion Delaney

ADVERTISING SALES MANAGERS

Stephanie J. Nolan

Angela Kays (Europe)

Marianne S. Ettisch (Classified)

Julie Skeet (Classified, Europe)

\begin{tabular}{lr}
\multicolumn{2}{c}{ MARKETING AND PRODUCTION } \\
MARKETING & PRODUCTION \\
MANAGER & MANAGER \\
Bruce Shriver, Jr. & Estelle B. Selzer
\end{tabular}

ASSISTANT PRODUCTION MANAGER Renée M. Roberts

PRESIDENT

James Skowrenski

NEW YORK

65 Bleecker St., New York, NY 10012

Tel: (212) 477-9600 Fax: (212) 505-1364 Editorial Fax: (212) 254-9493 MCI ID \#: 329-8956

\section{LONDON}

4 Little Essex St., London WC2R 3LF

Tel: (071) 872-0103 Fax (071) 240-2408

\section{SCIENTIFIC ADVISORY BOARD}

Leroy Hood (chair) University of Washington, Seattle Ken-ichi Arai Teruhiko Beppu Ronald E. Cape Jean-Pierre Changeux Mary-Dell Chilton

Nam-Hai Chua

Rita R. Colwell

Arnold Demain

J. Lawrence Fox David Goeddel Morio Ikehara

Ernest Jaworski Irving Johnson David Mount Victor Nussenzweig

George Poste George Rose Carl-Gustaf Rosen

Kendall Smith

Yukiall Smith

Marc Van Montag

Marc Van Mon
Indra K. Vasil

Indra K. Vasil

Wataru Yamaya

DNAX Research Institute University of Tokyo Darwin Molecular Technologies Institut Pasteur CIBA-Geigy Rockefeller University Maryland Biotechnology Institute Massachusetts Institute of Massachusett
Technology Amoco Technology Genentech Protein Engineering Research Institute

Monsanto Company

Consultant

University of Arizona

New York University Medical Center

SmithKline Beecham

Washington University

Abitec AB

Dartmouth Medical School

Takeda Chemicals

Plant Genetic Systems

University of Florida

Seikagaku Kogyo

Massachusetts Institute of

Technology

\section{/THE FIRST WORD}

\section{CRADA in un Deo Cruele}

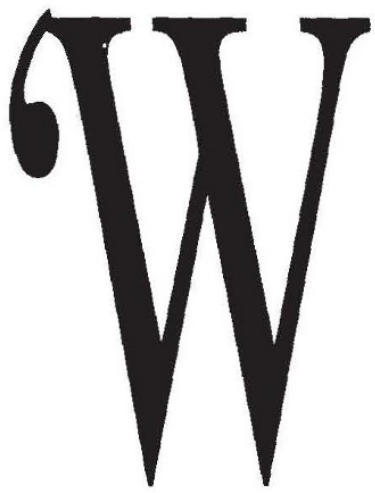

hat,' a friend asked, 'about private companies profiting from public life-science research?'

That raised some other questions. When do the U.S. National Institutes of Health resemble the Bureau of Land Management? How is a CRADA (collaborative research and development agreement) like the Mining Act of 1872 ?

More than a year-and-a-half ago, the National Cancer Institute's Bruce Chabner outlined in these pages his agency's rationale for entering into CRADAs aimed at bringing to market the antimitotic drug taxol, discovered and partially developed at NCI ("Taxol, A Test for Technology Transfer," Bio/Technology 9:1012, October 1991). At the time, Chabner seemed to present a reasonable extension of the Reagan-Bush policy of pushing as much development as possible into the private sector and onto corporate budgets. He responded to pricing complaints leveled by Ron Wyden, a U.S. congressman from Oregon.

So we watched in bemusement this winter as an increasingly shrill Wydento all appearances appalled by the excesses now being uncovered before himbaited Chabner and a remarkably composed executive from Bristol-Myers Squibb. During hearings, Wyden excoriated Chabner for handing a wonder drug over to price gougers, and laced into BMS for predatory pricing and for refusing to give precise numbers to justify the drug-maker's claim that high production costs demanded high retail price. (BMS does not itself produce taxol from Pacific yew bark: Hauser Chemical Research does that, using a proprietary extraction process.)

At about the same time, Time magazine ran a story (which read as though it had been drafted in the new Clinton White House) questioning the cost of Genzyme's Ceredase, the natural replacement enzyme therapeutic for Gaucher's disease. Once again, the U.S. taxpayer footed much of the R\&D bill-between a sixth and a fifth of the total. And public health insurance programs pay for about 20 percent of the drug's total sales. A year of treatment with the drug can cost a troubling $\$ 50,000$ to $\$ 350,000$. How can a private company charge so much for a product to which the public has contributed so much? The watchdogs call it profiteering. Privatizers call it a five-to-one return on the public R\&D investment. The drug makers say that's what it costs to produce.

It would be useful to see reliable figures justifying these astronomical prices, but it's hard to see how the drug makers or research officials deserve the bulk of the blame. These agreements are the inevitable result of policies that promoted willy-nilly commercialization of public property-both intellectual and realwithout securing any long-term public stake in the final product.

Now part of that goal is eminently justifiable. Public assets have long been used to lure entrepreneurs into the service of public goals. Private companies, not governments, drove the great waves of European exploration. They broke the roads, dug the canals, and built the railroads across continents. The excesses of the opportunists are legendary, of course, and the price they extracted has too often been too high. We are still living with the egregious Mining Act of 1872, which allows hardrock miners to open mines on public lands... and then to hold exclusive rights to their claims for just a few dollars an acre. We see the same eagerness to give away public grazing and timber lands. For the most part, though, the scoundrels are dead; what they built survives.

For the industry's good, as for the public good, we ought not accede to technology transfer where the benefits all accrue to one pan of the balance. As we must insist on continuing mechanisms that give industry access to the fruits of public research, we must also insist on giving something back - a royalty stream to pay for more research or treatment of the indigent, research materials, postdoctoral instruction. It will be an investment well worthwhile. 